This item was submitted to Loughborough's Research Repository by the author.

Items in Figshare are protected by copyright, with all rights reserved, unless otherwise indicated.

\title{
Socio-spatial mobilities and narratives of class identity in Britain
}

PLEASE CITE THE PUBLISHED VERSION

https://doi.org/10.1111/1468-4446.12624

PUBLISHER

Wiley @ London School of Economics and Political Science

VERSION

AM (Accepted Manuscript)

PUBLISHER STATEMENT

This is the peer reviewed version of the following article: MILES, A. and LEGUINA, A., 2018. Socio-spatial mobilities and narratives of class identity in Britain. British Journal of Sociology, 69 (4), pp.1063-1095, which has been published in final form at https://doi.org/10.1111/1468-4446.12624. This article may be used for noncommercial purposes in accordance with Wiley Terms and Conditions for Use of Self-Archived Versions.

\section{LICENCE}

CC BY-NC-ND 4.0

\section{REPOSITORY RECORD}

Miles, Andrew, and Adrian Leguina. 2018. "Socio-spatial Mobilities and Narratives of Class Identity in Britain". Loughborough University. https://hdl.handle.net/2134/36258. 


\section{Socio-spatial mobilities and narratives of class identity in Britain}

Andrew Miles

The University of Manchester

Adrian Leguina

Loughborough University

British Journal of Sociology

Version: Accepted

DOI: $10.1111 / 1468-4446.12624$

\section{Abstract}

In this article we carry out the most comprehensive analysis of social and spatial mobility in the UK to date and the first to directly link different dimensions of mobility to processes of social class formation. Using new analytical techniques in this field, we integrate quantitative and qualitative data from the 1958 Birth Cohort Study, combining text-mining and correspondence analysis in order to examine the intersection of geographical and social mobility with class identities. This work reflects a revival of interest in the spatialisation of class inequalities, which is connected to policy concerns about the regional dimension of Britain's mobility 'crisis' that have intensified in the wake of the 'Brexit' vote. We find that the South's role as an 'escalator' region for upward mobility has continued and that the relationship between social and spatial mobility both confirms and qualifies the role of London and the South East in generating inequalities. We show that different migration-mobility transitions are associated with distinctive and contrasting class identity narratives. Those 
who move from North to South stand out in particular for the way their 'class talk' reveals the social disorientation that attends their success. The contrasting ways in which other groups express their social identities suggests that the interplay of geographical and social mobilities play a crucial role in regional cultural divisions.

Keywords: Social mobility, spatial mobility, social class, identities, escalator region, National Child Development Study.

\section{Introduction}

In this article we address the important relationship between social and spatial mobility in the UK. We show that the South of England's role as an 'escalator' region for social mobility (Fielding 1992, 1995) remains intense, and also that those on the move geographically over the course of their lives handle their experiences of mobility quite differently to those who don't move or who return to where they were brought up. In a further demonstration of the magnetic power of London and the South East, which reinforces while qualifying its role in the reproduction of inequalities, we find that both middle-class and workingclass migrants have taken particular advantage of the concentration of opportunity in the capital and its hinterland. Applying new analytical techniques, we further show that the group which is doubly on the move in experiencing upward social mobility through migration from North to South stands out from the rest for the way its 'class talk' (Hill and Lai 2016) reveals shared personal stories of success mediated by dislocation and adjustment. This 
contrasts strongly with the more confident narratives of middle class migrants and the defensive and collective rhetoric employed by working class and regionally bounded groups.

Immediate background context to our work is provided by the recent spatial inflection given to policymakers' concerns that social mobility in the UK is 'in crisis' ${ }^{i}$ by the Social Mobility Commission's (SMC ${ }^{\mathrm{ii}}$ ) 'social mobility index' (SMCP 2016). This mapping exercise led the SMC to conclude that there were marked regional disparities in mobility chances between young people growing up in London and the Home Counties and their disadvantaged peers residing in former industrial areas, coastal towns and other provincial 'cold spots' for social mobility. The social mobility index does not in fact refer to measures of social mobility at all, but is based on various measures of deprivation that are presented as proxies for potential mobility chances. Nevertheless, the SMC's findings were brought into sharp focus a few months later by the results of the 2016 referendum on EU membership, in which the 'Leave' vote was subsequently shown to have correlated strongly with the SMC's 'low social mobility' areas (Sensier and Devine 2017).

'Brexit' raises the matter of social and spatial mobility in an urgent way. Issues of place and class have reverberated through the subsequent debate about why the Leave campaign won, with one particularly prominent strand of commentary arguing that it harnessed a provincial revolt of the 'left behind' against the metropolitan liberal elite (Moody 2016, Harris 2016, Goodwin and Heath 2016). Yet while the SMC's concerns have sparked a renewal of academic 
interest in the spatial distribution and regional dimensions of social mobility, most notably in Friedman's recent contributions with Laurison (2017) on elite mobility and the regional class pay gap, and with Macmillan (2017) on migration and opportunity hoarding, this work provides limited perspective on the crucial interplay between movement in social and physical space.

Labeled some thirty years ago as the 'missing link' in mobility research (Savage 1988), the impact of movement in physical space on social mobility outcomes has remained something of an impasse in UK sociology (see also Payne 2017). This is in contrast to sociological traditions elsewhere, for example in the United States, where a concern with the relationship between social and spatial mobility stretch back to Sorokin (1927), and which includes a large body of work in urban sociology on spatial mobility, residential segregation and social inequalities (e.g. Massey et al 1994). There has also been rather more attentiveness to this relationship in other disciplines, including the research by Fielding (1992) and others (e.g. Champion et al 2014) in geography, work in housing studies and regional planning (summarised by Friedrichs et al 2003), and in Chetty et al's recent $(2014,2016)$ studies of neighbourhood effects on income mobility from economics.

Our work in this paper moves both the sociological and wider field of mobility studies on by directly linking the social and spatial dimensions of mobility together while simultaneously examining their combined impact on questions of social and cultural identity. Here we focus, in particular, on the relationship between the experience of socio-spatial mobility and processes of social class 
formation. Such processes have been central to debates about the nature and implications of mobility in the UK, with critics of the 'Nuffield paradigm' (Goldthorpe 1987) arguing that class cannot simply be read off from changes in aggregate employment patterns (Savage et al 1992, Savage 2000). The contexts in which people are recruited to particular groups matters, as does the way those embarking on different pathways in relation to other members of their class interpret the transition between 'origin' and 'destination'.

There has been a significant amount of research on class identities in recent years (e.g. Savage et al 2001, Skeggs 2004, Ingram 2011; see also Bottero 2004). This includes work that, on the one hand, shows how the subjective experience of social mobility impacts class feeling in complex and sometimes negative ways (Lawler 2005, Miles et al 2011, Friedman 2016) and, on the other hand, has highlighted the ways in which the spatial dimensions to class are often crucial in generating identities and solidarities (e.g. Savage et al 2005, Benson 2014, Cunningham et al 2018). However, these approaches have remained largely separate, so that the dynamic, spatial and subjective aspects of class formation through social mobility have yet to be systematically examined.

We therefore bring together two analytical perspectives that have not previously been combined directly, and at large scale, in the mainstream sociological literature on social mobility and stratification: the first of which is concerned with the intersection of social and geographical mobility, and the second with the affective understandings of the migration-mobility transitions that result from this intersection. In part, this is because the development of 
work in the field of mobility geographies has been hampered by issues of methodology and data limitations (Favell and Recchi 2011). Our analysis in this paper overcomes these constraints by presenting a new type of 'mixed methods' approach in mobility research; one that directly integrates large-scale quantitative and qualitative data on mobilities and class subjectivities, thereby allowing us to move beyond static understandings of class inequalities.

\section{Space, place and mobility}

The concept of the 'escalator region' has been central to thinking about the spatialisation of social mobility in the UK. This is founded on the seminal research carried out by Fielding in the 1980s $(1992,1995)$. Based on a comparison of occupation and residence in 1971 and 1981 from census data from the Longitudinal Study, Fielding's work showed that London and the South East provided young in-migrants from the rest of the country with greater, accelerated opportunities for upward mobility than were available to them where they grew up, before they then 'stepped off' the escalator and moved away from the South East in mid and late career.

Friedman and Laurison's recent study (2017) takes issue with the escalator idea, specifically calling into question the SMC's depiction of London as the national 'engine room' of social mobility (2016). They use data from the 2014 Labour Force Survey (LFS) to analyse regional intergenerational mobility rates in the UK, linking these to class pay gaps in recruitment to elite occupations. Their findings show that spatial variation in the 'class ceiling' (Friedman et al 
2015, Laurison and Friedman 2016) is particularly marked in the Capital. Those upwardly mobile from working-class backgrounds into high status occupations in the capital are not only under-represented in such positions but receive substantially less pay than recruits with middle-class origins.

Building on research emanating from the Great British Class Survey (Savage et al 2013, 2015), which identifies the contemporary metropolis as a site of elite social closure, this work provides an important counter to the 'celebratory narrative' that surrounds London (see also Leguina and Miles 2017). However the notion of an escalator in Fielding's work is founded on the dynamic interplay between spatial and social mobility, and it is precisely this interregional dimension to mobility that neither the SMC's mobility index nor the regionally contained Labour Force Survey data employed by Friedman and Laurison can address. In consequence, Friedman and Macmillan (2017) have turned to explore this issue using measures of intergenerational mobility between regions from the Understanding Society panel study. These, they maintain, cast further doubt on the 'London effect' by indicating that domestic migration to London is dominated by those from privileged backgrounds, whose success in avoiding downward mobility inhibits the upward mobility of other class groups. Nevertheless, a proper evaluation of the engine room metaphor requires a more comprehensive assessment of the migration-mobility flows highlighted in the work of Fielding and his colleagues, including their implications for class formation as both a structural and a cultural process. 
The failure to further develop a combined perspective on mobility in UK sociology has both disciplinary and methodological roots; bound up, as Savage (2010) has shown, with the shifting boundaries of sociological analysis and jurisdiction in Britain since the 1950s. Interest in the socio-spatial dimension to mobility in fact harks back beyond the escalator hypothesis to an older tradition of work concerned with the local mechanisms of middle-class formation, which in the UK featured most prominently in the field of 'community studies' (Payne 1973). In this, the respective social trajectories of and resulting tensions between migrants and non-migrants, rendered variously as 'cosmopolitans' and 'locals' (Gouldner 1957) and 'spiralists' and 'burgesses' (Watson 1964), were the central focus. Subsequently, however, the perceived inability of the community studies tradition to illuminate the dynamics of modernization and globalization (Crow 2002) led to it being superseded by approaches that detach class from the social relations of place, simultaneously marginalizing its associational and normative dimensions.

This shift of emphasis was nowhere more evident than in the class structural approach to social mobility, shaped by Goldthorpe's seminal work in the 1970s and 80s, which came to define the field in the UK. Here, class is operationalised as a measurable variable based on occupational aggregates and their characteristic employment relations (Goldthorpe 1987, Erickson et al 1992). This approach was very powerful in terms of establishing the structural patterns and underlying dynamics of social mobility in these terms, and in providing the basis for cross-national comparisons of the same. However, as well as bracketing out the cultural and subjective dimensions of class, its 
quantitative focus and technical concerns are also associated with a 'methodological nationalism' (Chernillo 2011) that both averages over and obscures spatial variations in mobility between but also within national boundaries.

The empirical limits of this model of analysis have recently been highlighted by Favell and Recchi (2011) in a study of the relationship between spatial and social mobility in the European Union that revives the notion of London as an escalator region but within a wider 'European field' of social mobility. In this they combine mobility data from national surveys with personal mobility stories to argue for the disproportionate influence of European 'mobiles' who, according to the standards of the closed, nationally bounded aggregate approach, are counted as statistically insignificant outliers.

In the following sections of this paper we embark on a systematic development of this of type of approach, linking quantitative and qualitative data on different dimensions of mobility in order to reveal the relationship between its structural and subjective components. We draw our data for this analysis from the 1958 Birth Cohort Study, also known as the National Child Development Study (NCDS), combining panel data on social and geographical mobility with key elements of 'class talk' distilled from the text-mining of interviews. By reformatting the study of mobility in this way, we show, for the first time, how the dynamics of mobility - understood as an interrelated socio-spatial process give rise to particular narrative constructions of class. We find that the placebased qualities of mobility are more complex than the SMC suggests, precisely 
because of the missing inter-regional dimension. But we also show that the notion of a North-South divide in mobilities continues to carry weight, generating marked regional contrasts in life chances and class feeling.

\section{Data and Method}

The National Child Development Study

The NCDS is the flagship UK panel study. It began as a survey of perinatal mortality, involving a representative sample of 17,634 children born in one week in March 1958. Originally designed as a single wave study, there have since been nine sweeps investigating the biographies of panel members at age 7 in 1965, 11 (1969), 16 (1974), 23 (1981), 42 (2000), 46 (2004), 50 (2008), and 55 (2013). ${ }^{\text {iii }}$ These data have provided a remarkably rich account of this postwar generation's lives, including their social mobility trajectories, which have been the subject of a series of important studies (e.g. Breen and Goldthorpe 2001, Blanden et al 2004, Bukodi et al 2015, Egerton and Savage 1997, Goldthorpe and Jackson 2007). In 2008/09 the addition of a qualitative substudy that collected the life histories of 170 (later extended to 220) NCDS members further allowed the experience and subjective understandings of the patterns revealed by such aggregate studies to explored (Miles et al 2011). However the spatial dimensions of the NCDS in relation to social mobility remain largely neglected, limited to a study of anthropometric trait outcomes (Krzyzanowska and Mascie-Taylor 2012) and our own work, using the 
qualitative sub study, on regional class narratives (Cunningham et al 2018).

To examine this relationship we draw on both the NCDS panel data and the life history interviews. First, we set the scene by describing the pattern of geographical and social mobility in the NCDS as a whole, showing at a general level how inter-regional movements are linked to aggregate mobility flows and affect processes of demographic class formation (Goldthorpe 1987). We then pay particular attention to the sub-sample of 170 panel members who took part in the 'Social Participation and identity' project. iv This project was conducted to coincide with panel members reaching the age of 50 in 2008, and originally collected the experiences of individuals living in three areas of the UK: NorthWest and South-East England and Southern Scotland.v It therefore allows us to trace this sub-sample's migration-mobility trajectories and to directly link these to the interview participants' subjective understandings of their mobilities. More specifically, our analysis considers the spatial movements of this group by comparing their region of residence at interview with the region in which they were located at 16 (panel wave 3, in 1974, or three years earlier during wave 2 if this record was missing). Following the approach of the Social Participation and Identity study, we assess interviewees' social mobility by comparing their own social class at age 46 in 2004 (in the last wave completed before their interview, or at age 42 if data at 46 were missing) with that of their father when the participants in the sub-study were 16 (or 11). We then turn to the interviews themselves to consider the particular ways people with different migration-mobility profiles talk about their social class identities. 
There are a number of limitations with using NCDS data to index migration and mobility in this way. Relying on father's social position for class origin is not ideal but, in a reflection of the strongly gendered dynamics of the 1950 s economy, only fathers' occupations were classified into social groups. These, in turn, were based on the now outmoded Registrar-General's Social Class classification and on Socio-economic Group (SEG), which does not map directly on to the most widely used present-day scheme, but can be adapted to a reasonable approximation of the Erikson-Goldthorpe-Portocarero (EGP) scheme, which underpins the Office for National Statistics' National Statistics Socio-economic Classification (NS-SEC) (Connelley et al 2016). Here we adopt Savage and Egerton's (1997) approach to studying social mobility using the SEG classification in the NCDS. This approximates to the NS-SEC by amalgamating SEGs into a seven-class scheme, which we also use here in collapsed three-class and two-class versions.

Classification issues also affect analyses of migration in the NCDS. From the original perinatal mortality study through to wave 3 of the NCDS in 1974, variables for region were based on the Registrar General's Standard Regions (RGSRs). Subsequently, Standard Statistical Regions, and then from 1996 Government Office Regions (GORs), became the primary classification for regional statistics (Elliott et al 2012). In some cases, particularly across the south of England, there are marked variations in the boundaries used by the RGSR and the GOR classifications. These makes direct comparison, and therefore an entirely accurate assessment of inter-regional mobility across the whole NCDS sample, impossible. In order to mitigate this problem we have 
amalgamated the 11 regions variously specified by the RGSR and GOR schemes into four 'big regions': North, Midlands, South (England) and Scotland and Wales. ${ }^{\text {vi }}$ However, because the escalator argument focuses more directly on movement into the South East of the country, we also isolate movement from these big regions into 'London' and the 'South East' as defined in the GOR classification and from 'London and the South Eastern' as defined in the RGRS scheme.

Finally, in focusing on the migration-mobility experience of this cohort at age 46 and 50 indexed against their residential and class background in childhood, we are of course limiting our perspective to a cross-section of their mobilities at a particular moment in the lifecourse (Sørensen 1986). Movements, in both physical and social space, can and do take place both before and after this point. Timing, in this sense, is a particularly important component of the argument that London and the South East acted as escalator region for this generation, drawing young people in and accelerating their promotion, before they moved out again in late career and retirement (Savage et al 1992). It is therefore possible that some of this regional counter-movement is masked in the taking of a snapshot in middle age. On the other hand, the class-structural approach to the study of social mobility argues that it is precisely as this mid point in the life course that careers, for this postwar generation at least, were at their most stable (Goldthorpe 1987). 
The interviews conducted with members of the NCDS sub-study employed a semi-structured format, covering issues of belonging, participation, social networks and identities, and included a section dedicated to people's life stories (See Elliott et al 2010). Our analysis of the interview data for the effect of mobilities on the subjective dimensions of class focuses on the responses to a question within the identities section of the topic guide, which asked participants: 'Do you feel you belong to a social class?'. This was just one of 31 main questions asked in an interview that lasted, on average, for 90 minutes. Nevertheless, the transcribed responses to it from 170 people still amount to over 25,000 words of text. While we might proceed to read a selection of interviews to identify recurrent themes, this volume of information prohibits a broader account of the ways in which class identities are presented across the sub-sample.

In order to make this information more manageable, we first subjected interviewees' responses to the question about class belonging to text mining using QDA Miner and Wordstat software. We then examined their relationship to mobilities in a simple correspondence analysis (SCA) (Le Roux and Rouanet 2004, Greenacre 2007) carried out in SPAD 8. vii Text manipulation packages employ statistical techniques to uncover regularities across components of a text corpus, inductively revealing the common discourses and narrative structures it contains. SCA of textual data differs from topic modeling or equivalent approaches (e.g. DiMaggio et al 2013) in the way that it does not seek to classify respondents' narratives in terms of a (fixed) number of themes identified by word adjacencies. Rather, it allows the researcher to visualise, and 
thereby interpret, the overall distribution of keywords for each pattern of mobilities, as relations and meanings in common. Our approach, therefore, is not dissimilar from the analysis of textual data proposed by Lee and Martin (2015), the advantage being that it allows us to minimise issues with the process of codification, or statistical classification, identified by these authors.

The procedure rests upon the construction of 'dictionaries' with which the texts are compared after a process called 'lemmatisation', which standardizes forms and tenses of nouns, verbs, adjectives and adverbs derived from the same root word (Stoneman et al 2012; Provalis 2015: 11). In our analysis the resulting dictionary of class identity narratives is composed of a total of 106 unique entries. Dictionary construction can be summarized as a semi-automatic extraction of relevant keywords and phrases that compose, in our case, class identity narratives. To start with, function words (such as 'a', 'the', 'or', etc.) are excluded from the analysis, and remaining text is processed, including lemmatization, the correction of spellings, detection of common phrases and exclusion of irrelevant words. Content to be retained is stored in a 'category dictionary', while, an 'exclusion dictionary' stores the textual 'residue'. The retained text constitutes the one half of the input for next stage of the an.

Our specific aim was to explore the relationship between words and short phrases that compose narratives of class identity and patterns of mobilities. So, in a second step, we amalgamated four social mobility groups with the two geographical mobility states of 'movers' and 'non-movers' into one mobilities variable. Here geographical movement was indicated, as we describe above, by 
whether or not interviewees were living in the same region when interviewed in 2008 as the one in which they grew up. However for social mobility we used a collapsed two-class model, defining the following types of mobility: 'stable service' - men and women in service class jobs who had also grown up in service class families; 'upwardly mobile' - those moving into service class jobs from working- and intermediate class origins; 'downwardly mobile' - those moving into working- and intermediate class jobs from service class origins; and a 'stable other' group of interviewees who had remained in the same types of working and intermediate class jobs as their parents.

The analysis of class identity responses, grouped by the resulting eight mobilitymigration combinations, seeks to detect if individual narratives are expressed using similar words, which would indicate the occurrence of shared mobilitymigration narratives as consequence of shared life trajectories. Our final step was therefore to carry out this analysis by combining the extracted words and phrases as rows with patterns of mobilities (plus relevant socio-demographic indicators) as columns and entering the resulting lexicological contingency table into a SCA. This technique provides a means to graphically represent a space of word-sets and patterns of mobility-migration in a low-dimensional (frequently two) factorial space, where closeness between words indicates co-occurrence and closeness between patterns of mobility-migration indicates similarities in the co-occurrence of word-sets. viii

\section{Analysis and Discussion}


The mobilities of the NCDS generation

We begin by inspecting the general patterns of migration and mobility in the NCDS panel data as whole. This allows us to sketch out the broader context in which the experience of the NCDS sub-study interviewees was set.

**Table 1 here

Table 1 shows the class distribution by origin, or outflow mobility, of NCDS panel members at age 46 or 42 , using the seven-class SEG scheme, according to whether or not they were living in the same big region at interview compared to the one in which they grew up. An initial point to note here is that geographical movement, in these broad terms, was relatively unusual, involving just over one in five of those remaining in the study in 2004. As mentioned, this may reflect regional counter-mobility. It may also reflect higher rates of panel attrition among those on the move (Uhrig 2008). Otherwise, it seems to suggest the 'stickiness' of regional affiliation.

The second point to highlight from this analysis is that there is a positive association between migration and mobility, though in terms of the total mobility rate, it was not substantial. The NCDS panelists were part of a generation that experienced rising chances of mobility, particularly upward social mobility, which was encouraged by the expansion of professional, 
managerial and service sector employment and the contraction of manual working-class jobs associated with manufacturing, mining and agriculture (Goldthorpe 1980, Goldthorpe and Jackson 2007). The summary statistics for Table 1 show that more than half of the remaining participants in the NCDS had become upwardly mobility by the time they reached their mid 40s. Overall, however, movers were only marginally more upwardly mobile, and slightly less downwardly mobile, than those who stayed put in (or left but then returned to) their region of origin.

Yet the total mobility rate is a misleading measure on two fronts. Firstly, inspection of the specific class destinations of movers and non-movers in Table 1 indicates that movers from almost all class origins were more likely than nonmovers to be found in service-class jobs in mid-career, as well as less likely than them to appear in working class positions and self-employment. Hence more upward working and intermediate class mobility among movers was at the same time offset by greater service-class stability. Secondly, what the total mobility rate for movers and non-movers also masks is the source and direction of migration, or its inter-regional dynamics.

We address these dynamics in Table 2 , which presents the social mobility rates of NCDS members at age 46/42 according to their regional origins and destinations. Introducing the regional dimension puts pressure on sample numbers at this level so we use a three-class version of the SEG class scheme in this analysis. 
**Table 2 here

Fielding et al's original work on the escalator idea drew on census data from the 1971 and 1981 to investigate middle-class careers (Fielding 1992, 1995; Savage et al 1992). The migration-mobility patterns shown in Table 2 provide strong evidence that the South of England has continued to act as an escalator region for the generation that followed, whose careers matured in the early 2000 s. Those originating in northern working-class families and migrating to London and the South East had almost double the chances of reaching a service-class position (66\%) compared to those from the same class who remained in or returned to the North (35\%), while the advantage of those starting out in the Midlands was even greater (69\% : 29\%). These working-class migrants from the North and the Midlands also out-performed the 'local' working-class in the competition for service class jobs in the South East (33\%) to a similar degree. Upward mobility through migration further provided this migrant group with more access to the service class than middle-class children who remained in or returned to the North (53\%) or the Midlands (50\%) and even the children of service class parents in the South East (55\%).

However, the regional mobility flows indicated in other parts of Table 2 also suggest the need for some qualifications to the original escalator region argument. Firstly, migration to the South not only boosted the chances of upward mobility for those growing up in working-class families in the North 
and the Midlands. It also significantly increased the chances (by $45 \%$ and $70 \%$ respectively) of migrant service-class children from these regions maintaining their middle-class status when compared to those who stayed put. Arguably then, despite the very considerable returns to migration to the South enjoyed by the children of working class families in the North and the Midlands, it was their middle-class migrant peers from the same regions - $77 \%$ and $84 \%$ of whom were able to secure a service-class position themselves - who were as much the beneficiaries.

Savage et al (1992) argued against there being a marked structural effect - in terms of regional service sector concentration in the South East - driving the escalator in the 1970s and 80s. Since that time, however, spatial imbalances in the UK economy between North and South have widened (Gardiner et al 2013), driven by the success of London and the South East in harnessing the growth of the finance and business-led service economy, which, in turn, has encouraged a flow of human, as well as capital, resources to the faster growing and more prosperous South (Rowthorn 2010). This seems to be reflected in a generalised pattern of relative career advantage accruing to NCDS panelists moving to the South East. Nevertheless, migration-mobility flows indicated elsewhere in Table 2 , testify to continuing complexities in this relationship. It was not only the southern service economy that offered a pathway to success. The Midlands also offered opportunities for a substantial uplift to working- and intermediate-class migrants from both the North and the South, relative to those staying put, while the chances of upward mobility for those with fathers in intermediate class jobs 
who moved to the North from the Midlands and the South as high or even higher for those moving in the opposite direction.

In the next section of this paper we are interested in unpacking how such movements in geographical and social space impacted on the class identities of NCDS panel members. Important context for this is provided by looking first at the structural impact of mobility from the opposite direction to that presented by the outflow patterns in Table 2: in other words, how the influx, or inflow mobility, of new recruits affected the demographic integrity of their destination class. Given the recent focus in mobility research on elites and in particular the social and psychological experience of long range upward mobility into the higher reaches of the class structure (Friedman 2016), we concentrate here on recruitment to the service class (Table 3).

\section{${ }^{* *}$ Table 3 here}

The patterns in Table 3 shows some apparently contradictory as well as contrasting characteristics in the regional recruitment profile of the service class, which are clearly driven in part by regional variations in occupational structure. At this three-class level, the service class appears relatively 'open' in all regions, recruiting a large majority of its membership from below. In these terms its profile is most heterogeneous in the North and the Midlands, where rates of service-class self-recruitment are just one in six and one in eight respectively, while 50 per cent of recruits grew up in working class families. It is least fluid in the South, where workers' children occupy less than 40 per cent of 
service class positions. However, the relative openness of the service class nationally in social terms contrasts strongly with the degree of regional 'closure' it displays in all three regions. Thus 'locals' dominate everywhere, and particularly in the North and the South, where migrants make up only a fifth of the membership. And despite the high rates of upward mobility enjoyed by working class migrants from the North and Midlands who moved into to the South, their absolute numbers relative to the size of their destination class means that they occupied just $3.8 \%$ and $3.2 \%$ of service class jobs, rendering them, in these terms, rather isolated minorities.

\section{Mobilities and class identity}

In this final section of the paper we turn to how members of the NCDS handled their mobilities in terms of the 'class talk' expressed in their interviews. As explained above we combine text-mining techniques with simple correspondence analysis to detect whether there are any significant variations in the narratives of the 170 NCDS sub-sample according to their mobility profile. We focus out attention on the first three axes of the SCA, ix which together account for almost 60 per cent of the retained variance explained. $\times$ The SCA plots in Figures 1 and 2 below can be read in conjunction with the Tables A2 and $\mathrm{A} 3$ in the Appendix to this paper, which quantify the contributions of the top 20 word-sets and the eight mobility-migration patterns.

The first axis of the SCA ${ }^{\mathrm{xi}}$ is strongly demarcated by the class identity narratives of upwardly mobile migrants (upward \& mover) on the upper left-hand side of 
Figure 1a. This is therefore the most distinctive group across the whole subsample in these terms. Its members talk about class in a different way to other groups, particularly people in working-class and intermediate positions (stable other) to the right of this axis.

\section{**Figures 1a, 1b and 1c here}

Here we can see that the narratives on the left-hand side of Figure 1a more often contain terms relating to achievement ('successful', 'aspiration'). This is particularly the case in the upper left quadrant, where, as the distribution of the supplementary variables shown in Figure 1b indicates, those whose upward social mobility has taken place in conjunction with geographical mobility from North to South are located. This is also the space in which there is more objective experience (as well as talk) of graduate-level education and professional employment. Vocabularies of success are, however, mixed with and tempered by expressions of diffidence ('luck', 'humble') that recall renditions of the 'modest career' detected by Miles et al (2011), in which the upwardly mobile try to downplay or deflect from their achievements. On this side of the analysis, we also find references to mechanisms of social mobility ('career', 'qualification') and also to middle class status ('professional', 'manager', 'teacher', 'privilege'). 
By contrast, on the right-hand side of the space, there is more mention of economic circumstances and constraints ('not a lot of money', 'work hard' 'poor', 'afford'), and while on the left-hand side of the axis classification issues are more often refracted through neutral status terms, there appears to be more loaded 'class talk' on the right. This is indicated by the positioning of references to economic and social relations ('wealthy others', 'Oxbridge') on this side of the axis; and to social judgment ('snob', 'not judge'). These narratives are also more associated with lower levels of educational achievement, and with small business.

The horizontal Axis 2 is then also defined predominantly by the discourses of the upwardly mobile but in this case those who were geographically static (upward \& no mover). This group is more likely to be located in the North than the South, and its narratives are counter-posed to those of people in workingand intermediate-class positions who are also located in the same region that they grew up in (stable other \& no mover, downward \& no mover). Reading from top to bottom across Axis 2, upwardly mobile non-movers talk, like their migrant peers, about middle-class identity, educational opportunity and good fortune. However, they also seem more willing to acknowledge the crossing of class boundaries, through mention of earnings and lifestyle, if not culture. Rather than success, they emphasise the hardship and struggle associated with their working-class backgrounds. Meanwhile, the lower side of Axis 2 features narratives which are shaped around indirect forms of class awareness: cultural references to class difference ('accent', 'rough', stigma', 'poshness'), and also resistance to classification altogether ('no class identity'). 
This approach also allows us to return to the full interviews themselves in order to identify and expand upon representative cases. ${ }^{\text {xii }}$ A notable characteristic of the doubly mobile individuals whose narratives dominate the first axis, for example, is that they are often highly self-aware in relation to and expansive about classification issues. They are resistant to being pinned down, talk about having a mixed or uncertain social identity, and often express insecurity about their social position. Emphasis is placed on the role of good fortune and educational opportunity in their success. For example, P57, a medical professional living in the South East who grew in Yorkshire, eventually concludes that he is 'very, yeah professional, kind of middle class without any doubt', but prior to this his narrative combines all of these tropes:

I think I belong to the kind of lucky lot really. You'd have the success of education, you have the success of the universities in the '60s and then I--, we got full grant...I look back now and I just, we're so fucking lucky....

It was working class, I mean that was me father's definition, that's what he thought himself as, and again that was kind of--, I mean there's all these sort of rivalries and kind of, well it's not really working class and all that crap, 'cause I mean he had a kind of fairly skilled job, he was a draughtsman and so he wasn't a manual worker...

And also the kind of hobbies and the kind of things were quite--, and his music--. Quite middle class pursuits...--, but we weren't kind of part of that 
either 'cause we didn't have the money that they had, so it was like you were never quite belonged to anything.

P69, who moved from a working-class community in the East of England, to become a teacher in the South indicates the scale of social and cultural adjustment that some spiralist trajectories could involve:

Where we grew up was a bit like a one fork town, all added together. And you did, everyone concurred a lot, there were more social pressures, I think maybe that's a sign of the times... And I can remember coming to Brighton thinking, bloody hell, the roads are so wide, and I was phoning [my mother] up saying--, and I had to cross the road, you know...so I think coming here, it's probably top middle class, isn't it, Brighton? You've got your "Hove actually" mothers, as I call them, they're all in, hmmm, but you've also got that real, yeah as you say, diverse people who are contradicting the world and they would be seen as middle class in Brighton but I don't know what they'd be seen as anywhere else. So the wedding down the road was a lesbian wedding that we went to on Saturday, and all the neighbours went. I just said, [in one fork town] “...it would be different," so it is different, totally different. But here you do--, I do think about it. I do think twice

The way in which the disorientation caused by such journeys might shade over into insecurity, indicating the emotional imprint of mobility (Friedman 2016), is 
evident in the narrative of P675, a chartered surveyor, who talks about the discomfort of feeling socially out of place in the company of members of the established middle class:

I suppose I've always considered myself to be middle class whatever that means, I mean, I know there's different socioeconomic groups now. I'd--, I've always felts sort of, you know, we came from relatively humble roots, I mean, I was born in a council house in [North-West city]...

I've got quite a lot of teacher friends and I've got a lot of people who come from, you know, more sort of blue collar type jobs, you know,... To a certain extent I find it quite comfortable, I mean, we've got a couple of doctor friends, one in particular that we see from time to time and I find it--, I find his company--, he's a very nice man but I find his company quite difficult because I see him as being highly educated, very intelligent and I feel that everything I'm gonna say is gonna sound stupid. So to a certain extent, you know, I feel more comfortable with, you know, people I can probably talk at rather than talk to.

The rhetoric of upwardly mobile non-movers, on the other hand, tends to be both more certain and less individualistic, more often identifying shared roots and common trajectories. P305, a northern solicitor, while playing down her upward mobility, recognises it in terms of collective class success: 
'I think I still think of myself as working class, 'cause of my background. But I think I would be seen to be lower middle. Yeah, and I think there are, well, hundreds of thousands of us, more, probably millions, who come from a working class background'.

P019, a civil servant in the North-West, talks about the common upward mobility experience of his peer group, rooted in working-class friendship networks and sustained through regional circuits of state employment:

And I suppose it's that crossover point, working to middle class I suppose, I mean, whatever they call it these days, I don't know. I say working class because if I didn't work then I can't afford to do the things I want to do, so. But then the lifestyle I've got with working is probably more middle-class, yeah... and probably like the social group of people, you know, we're all similar in--, I mean it's amazing...They're either friends I've had, I mean, from me childhood or friends who I've met later and they either work--, for the civil service or National Health, local government, although--, we're all very similar jobs... But I think, again, you know, like over the years--, we probably all started off lower down the ladder and, you know, we've all had our promotions and moved on and upwards and, you know...

\footnotetext{
**Figures $2 \mathrm{a}$, and $\mathbf{2 b}$ here
} 
Unlike the first two axes, the third (Figure 2a and $\mathrm{b}$ ) is defined by class position and geographical movement rather than social mobility. This axis is differentiated, in particular, by the way in which second-generation members of the service class who have moved away from their region of origin (stable service \& mover) talk about social class. Here, the word-sets making the highest contribution to the axis, located beneath the horizontal, signal more direct and overt class talk ('social divide'), including the indicators and mechanisms underpinning the maintenance of middle-class status ('Grammar School', 'Private School', 'University', 'Nice House'] and a concern with politics ('Conservative', 'Labour').

The interviews themselves ${ }^{\text {xii }}$ show that members of this socially stable but geographically mobile service-class group are generally quite assured, informed and even enthusiastic when discussing class ('I'm very interested in class, I'm very interested in that kind of whole thing. I--, if--, you know--, that is something that I could rabbit on about for a while', P440, managing director of a factory). They recognise and talk about the existence of a 'class system', although a number use their knowledge to problematize it, and to qualify their own position within it. Here 601, a business consultant, talks about the complexities of classification in the present day compared to the past, while misclassifying himself in the process.

Q: $\quad$ Do you think of yourself as belonging to a particular social class?

A: Hmmm, that's a tricky question because obviously I'm thinking 
about that from a work perspective a lot--,

Q: $\quad$ Right.

A: $\quad$ Not for me, but the whole the whole idea of $A B C 1, C 2, D E$, which is interesting because then the whole--, the whole things moved on into things like--, into geodemographics. So the whole idea of MOSAIC and ACORN and stuff like that, if you're familiar with those....

A: $\quad$ So MOSAIC is, yes--, so that's quite interesting. You know, it would be quite interesting to get the 59 areas out and go, 'Yes, we're in that one.'

Q: Aha.

A: I'm sure--, I'm sure we would be able to do that because the whole strength of the system is that everybody--, everybody is in one of them. So I'm sure we would--, I don't know which one it would be. I mean obviously in the oldie days we'd have been $\mathrm{C} 1$.

Q: $\quad$ Did you feel you belonged to a particular social class growing up?

A: Hmmm, I think in those days it was much simpler. You were either ... or... class. And yeah, very definitely slap, bang, middle class. Q: Right. Why's that' How did you get that sense? A: $\quad$ My dad was a company director, we had a nice house, I went to a grammar school, and we had nice holidays. My dad had--, my dad had a company car, and my mum had a company car. We had our phone bills paid for so we were doing okay. 
These loquacious narratives, in which respondents are willing to demonstrate their awareness of class while dabbling in classification games, stand in quite stark contrast to the discourses prevailing on the higher side of Axis 3. These belong to socially stable working- and intermediate-class located in the same region in which they grew up, which is more likely to be the North than the South. Here, content is focused on resisting class by making claims to normality ('Normal Person') and by references to a more restricted sphere of experience based on family and social proximity ('Neighbour', House Home'). The full texts then show that these working- and intermediate-class non-movers are characteristically more perfunctory, defensive and uncomfortable when asked about their class identity. Class is dismissed as a label applied by others, that they seek to resist and to distance themselves from by rejecting snobbery and by stressing their individuality, ordinariness, and independence.

No. No. No, I don't see myself that way at all, no. No.... I think a lot of the time I think that's what somebody else labels you rather, you know, but I don't see myself as working class or middle class, I'm just--, I don't know, I'm just a normal person... I don't know, whether other people think I'm working class, it wouldn't bother me. I don't think of myself as working or middle class or certainly not upper class. [laughs] So no, and it doesn't bother me, no. (P273, joiner)

It's difficult to answer. I'm not a snob or anything like that. I don't really know how to answer that question as such, hmmm, I don't really 
know how to answer that I'm afraid... I'd just say a normal working class person...I've never been on the dole or anything like that, I've never claimed for anything. (P268, general operative)

I don't really like the class thing....Well I don't think I would want to put myself in any specific class. [Pause]. I mean I don't like the term sort of 'working class' because I mean I think a lot of us are all working class, we go out to work and I don't--, I don't--, you know, that some people aspire to be--, I mean we all want to be better and have more money and have nice things, but I don't really like the term. (P505, station assistant)

I don't like getting put into a category. See this, middle class, working class, I just don't like that. It's trying to put individuals in a bracket, and yeah, I'm an individual but I'm not in a bracket, so no, I wouldn't--, I wouldn't put myself anywhere. (P609, quality inspector)

To summarise, by combining text analysis of interviews with geometric data analysis we are able to distil strong patterns in and contrasts between the class narratives of NCDS members with different social and spatial mobility trajectories. Both types of mobility shape the way in which class identities are handled but the clearest divergences are produced through their interaction. Thus it is the content and style of upwardly mobile movers' class talk, emphasizing cultural disorientation and the contingent nature of their social success, which is most distinctive. This can be compared with the more 
anchored and collectively focused rhetoric of upwardly mobile non-movers, and also the more assured performance of middle-class migrants in handling the issue of class, whose expansive accounts stand in marked contrast to the closed and evasive responses of those who are neither socially nor geographically mobile.

\section{Conclusion}

The relationship between social and spatial mobility has been neglected in UK sociology. While studies of social mobility in the British context have bracketed out place, research on the spatial dimensions of inequality hasn't had much to say about how these might be informed by mobility processes. The main exception to this is research in human geography from the 1980s, which argued that London and the South East acted as an escalator region, promoting the upward mobility of working-class in-migrants from the North. Recent policy concerns about the regional dimensions to Britain's social mobility 'crisis' has generated renewed interest in the geographies of social mobility but this work remains spatially contained and thereby fails to capture the crucial interplay between migration and mobility. The subsequent Brexit vote, which in some assessments exposes deep cultural divisions founded on place and class, highlights the importance of reaching a better understanding of this relationship. 
In this paper we apply a new combination of analytical techniques to data from the 1958 Birth Cohort Study in order to carry out a systematic, integrated analysis of socio-spatial mobilities and their impact on class identities. We show that the role of the South of England as an escalator region, first identified by Fielding in the 1980s $(1992,1995)$, remains intense. In doing so we provide some support for the SMC's (2016) contention that London is an 'engine-room' for upward social mobility. Working-class men and women migrating to the South from the North and the Midlands have much higher rates of success in achieving social advancement than their regionally static peers. These incomers also substantially out-perform the children of local working class people in this way and are even slightly more likely than those growing up in the southern service class to gain entry to a service-class job.

In contrast to studies pointing to the domination of service class privilege and the relative impenetrability of the Capital's 'class ceiling' (Friedman and Laurison 2017, Friedman and Macmillan 2017), this suggests that London and the South East are not simply a source of rising and accentuated inequalities. The fact that migration from the North and Midlands was needed to enhance the prospects of both those moving up the ladder and those seeking to maintain their middle-status is certainly a powerful demonstration of the capital's 'vortex' effect in draining other parts of the country of talent. Yet working class migrants to the South experienced a very considerable uplift in prospects by comparison with other members of their origin class. Meanwhile, there were also improved prospects for those whose journeys stopped short, in the Midlands, as well as those travelling in the opposite direction entirely. 
When we turn to the effects of these mobilities on class identities and relations we find evidence that those moving down from the North to ride the southern escalator are a particularly distinctive group, whose experience supports but also extends the argument that upward social mobility can leave a negative 'emotional imprint' (Friedman 2016). The combined long-range mobilities of this group exact a toll. Their talk of success is qualified by feelings of social disorientation. Doubly uprooted, their identities are mixed and uncertain. These sentiments seem to be reinforced by the relative social and cultural isolation of this group structurally, with upwardly mobile movers from the North comprising less than 4 per cent of the southern service class. While all inmigrants end up as minority groups in this sense, those with middle-class backgrounds who move to the South speak with much more assurance and confidence than their upwardly mobile peers. Their ability to engage with issues of class and identity suggests they have the 'cosmopolitan' cultural capital with which adapt to their new circumstances.

Our findings testify to the importance of working with an expanded conception of class formation, as both a structural and cultural process, that is imprinted by more than one dimension of mobility (Savage 2000). This approach complicates the picture of mobility and class in the UK drawn by national surveys of occupational class mobility alone. It also points to the complexities that underlie the socio-spatial dimensions of political feeling (Goodwin and Heath 2016, Sensier and Devine 2017). The narratives of those who are 'left behind' by the southern escalator give some weight to the notion that the intersection of 
spatial and social inequalities in the UK helps to define and reinforce regional cultural divisions. Here too, however, very distinct and different forms of class talk emerge to indicate intra- alongside inter-regional demarcations. In this case the defensiveness and restricted horizons of the northern working-class contrasts strongly with the expansive and engaged class talk of the middle class in the South, as does the more collectivist rhetoric of northern upwardly mobiles when compared to the more ambivalent, individualist talk of those who left to seek advancement in the South. Yet while those leaving their workingclass backgrounds acknowledge the struggles and hardships of their parents, which are shared by contemporary members of that class, there is nothing further to suggest any convergence in the sentiments of different class groups in the North.

Word Count: Text and references 10,828 


\section{Tables and Figures}

Table 1. Social mobility (seven classes) by geographical movement (per cent)

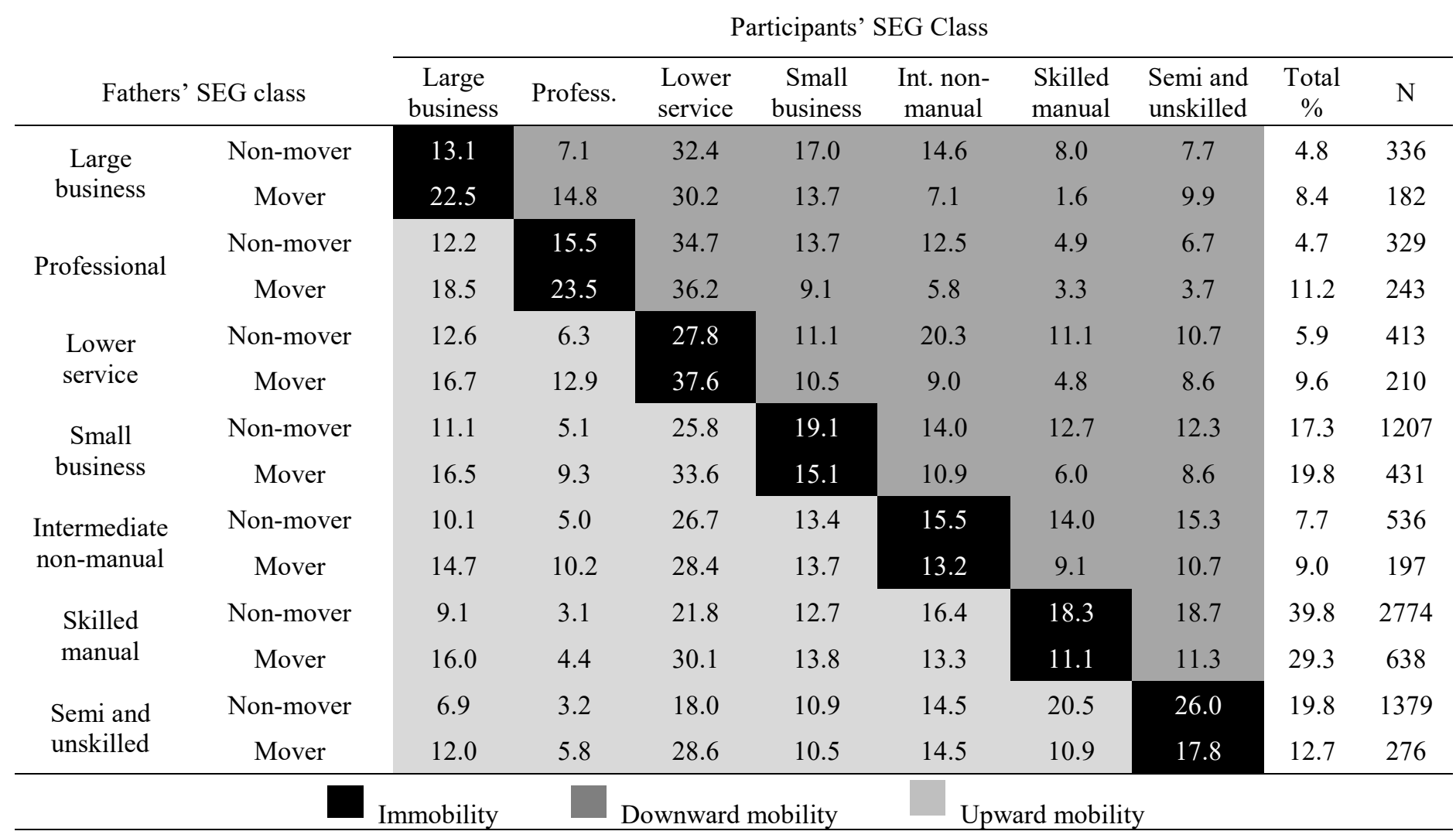

Supplementary statistics - total mobility rates (upward and downward)

\begin{tabular}{cccc}
\hline & No mover & Mover & $\mathrm{N}$ \\
\hline Socially Stable & 19.9 & 17.8 & 1777 \\
Upwardly mobile & 52.9 & 55.9 & 4905 \\
Downwardly mobile & 27.2 & 26.3 & 2469 \\
\hline Total & 76.2 & 23.8 & \\
& 6974 & 2177 & \\
\hline
\end{tabular}


Table 2. Social mobility by regional movement (per cent)

\begin{tabular}{|c|c|c|c|c|c|c|c|c|c|c|c|c|}
\hline & \multicolumn{4}{|c|}{ Service class outflow mobility by region } & \multicolumn{4}{|c|}{$\begin{array}{c}\text { Intermediate class outflow mobility by } \\
\text { region }\end{array}$} & \multicolumn{4}{|c|}{ Working class outflow mobility by region } \\
\hline & Stable S & $\begin{array}{c}\text { Down } \\
\mathrm{S}>\mathrm{I}\end{array}$ & $\begin{array}{l}\text { Down } \\
\mathrm{S}>\mathrm{W}\end{array}$ & $\mathrm{N}$ & Up I $>S$ & $\begin{array}{c}\text { Stable } \\
\text { I } \\
\end{array}$ & Down $\mathrm{I}>\mathrm{W}$ & $\mathrm{N}$ & $\mathrm{Up} \mathrm{W}>\mathrm{S}$ & $\mathrm{Up} \mathrm{W}>\mathrm{I}$ & $\begin{array}{c}\text { Stable } \\
\text { W }\end{array}$ & $\mathrm{N}$ \\
\hline \multicolumn{13}{|l|}{$\begin{array}{l}\text { Regional } \\
\text { migration }\end{array}$} \\
\hline North $>$ North & 53.2 & 25.4 & 21.4 & 295 & 42.8 & 30.7 & 26.5 & 456 & 34.5 & 26.2 & 39.3 & 1313 \\
\hline North $>$ Mids & 77.3 & 13.6 & 9.1 & 22 & 69.0 & 27.6 & 3.4 & 29 & 50.8 & 30.8 & 18.5 & 65 \\
\hline North $>$ South & 74.7 & 14.9 & 10.3 & 87 & 54.4 & 27.9 & 17.6 & 68 & 59.1 & 15.7 & 25.2 & 115 \\
\hline North $>L \& S E$ & 76.7 & 12.8 & 10.5 & 47 & 52.6 & 34.2 & 13.2 & 38 & 65.5 & 14.5 & 20.0 & 55 \\
\hline North $>$ Other & 57.1 & 35.7 & 7.1 & 14 & 50.0 & 28.6 & 21.4 & 14 & 48.1 & 29.6 & 22.2 & 27 \\
\hline Mids $>$ North & 69.0 & 20.7 & 10.3 & 29 & 63.4 & 22.0 & 14.6 & 41 & 36.1 & 32.8 & 31.1 & 61 \\
\hline Mids $>$ Mids & 49.7 & 30.3 & 20.0 & 155 & 41.9 & 30.9 & 27.2 & 272 & 29.2 & 28.2 & 42.6 & 812 \\
\hline Mids $>$ South & 79.0 & 17.7 & 3.2 & 62 & 64.9 & 19.3 & 15.8 & 57 & 60.0 & 27.4 & 12.6 & 95 \\
\hline$M i d s>L \& S E$ & 84.0 & 16.0 & 0.0 & 25 & 65.4 & 23.1 & 11.5 & 26 & 69.2 & 21.2 & 9.6 & 52 \\
\hline Mids $>$ Other & 60.0 & 20.0 & 20.0 & 5 & 45.5 & 27.3 & 27.3 & 11 & 41.2 & 29.4 & 29.4 & 17 \\
\hline South $>$ North & 65.6 & 18.8 & 15.6 & 32 & 57.7 & 30.8 & 11.5 & 26 & 46.5 & 30.2 & 23.3 & 43 \\
\hline South $>$ Mids & 64.3 & 19.6 & 16.1 & 56 & 61.7 & 12.8 & 25.5 & 47 & 53.7 & 24.1 & 22.2 & 54 \\
\hline South $>$ South & 57.5 & 30.3 & 12.2 & 720 & 44.1 & 32.3 & 23.6 & 1018 & 33.4 & 30.6 & 36.0 & 1555 \\
\hline$L S E>L \& S E$ & 55.2 & 32.5 & 12.0 & 252 & 46.3 & 31.4 & 22.3 & 341 & 32.5 & 32.5 & 34.9 & 538 \\
\hline South $>$ Other & 69.6 & 13.0 & 17.4 & 23 & 38.9 & 55.6 & 5.6 & 18 & 38.9 & 27.8 & 33.3 & 18 \\
\hline
\end{tabular}

Key

Mids: Midlands

Other: Scotland, Wales and Northern Ireland

L\&SE: London and South East (GOR)

LSE: London and the South Eastern (RGRS)

S: Service class

I: Intermediate class

W: Working class 
Table 3. Service class inflow mobility by region (per cent)

\begin{tabular}{lcccc}
\hline \multirow{2}{*}{ Regional migration } & \multicolumn{3}{c}{ Origin Class } & \\
\cline { 2 - 4 } \cline { 5 - 5 } \cline { 5 - 5 } North $>$ North & Service & Intermediate & Working & $\mathrm{N}$ \\
Mids $>$ North & 16.4 & 20.4 & 47.3 & 805 \\
South $>$ North & 2.1 & 2.7 & 2.3 & 68 \\
Other $>$ North & 2.2 & 1.6 & 2.1 & 56 \\
Total & 1.6 & 0.5 & 0.8 & 28 \\
& 22.3 & 25.2 & 52.6 & 957 \\
North $>$ Mids & & & & \\
Mids $>$ Mids & 2.8 & 3.2 & 5.3 & 70 \\
South $>$ Mids & 12.5 & 18.4 & 38.3 & 428 \\
Other $>$ Mids & 5.8 & 4.7 & 4.7 & 94 \\
Total & 1.1 & 1.0 & 2.1 & 26 \\
& 22.2 & 27.3 & 50.5 & 618 \\
North $>$ South & 3.6 & 2.1 & 3.8 & 170 \\
Mids $>$ South & 2.7 & 2.2 & 3.2 & 143 \\
South $>$ South & 23.2 & 25.2 & 29.1 & 1382 \\
Other $>$ South & 1.4 & 1.4 & 2.1 & 87 \\
Total & 31.0 & 30.8 & 38.2 & 1782 \\
& & & & \\
North $>$ L\&SE & 3.6 & 2.0 & 3.6 & 92 \\
Mids $>$ L\&SE & 2.1 & 1.7 & 3.6 & 74 \\
South $>$ L\&SE & 24.2 & 25.2 & 28.1 & 767 \\
Other $>$ L\&SE & 1.5 & 1.9 & 2.3 & 57 \\
Total & 31.5 & 30.8 & 37.7 & 990 \\
\hline
\end{tabular}

Key

Mids: Midlands

Other: Scotland, Wales and Northern Ireland

L\&SE: London and South East (GOR)

LSE: London and the South Eastern (RGRS) 
Figure 1a. Axes 1 and 2 active categories

Cases - Axes 1 \& 2

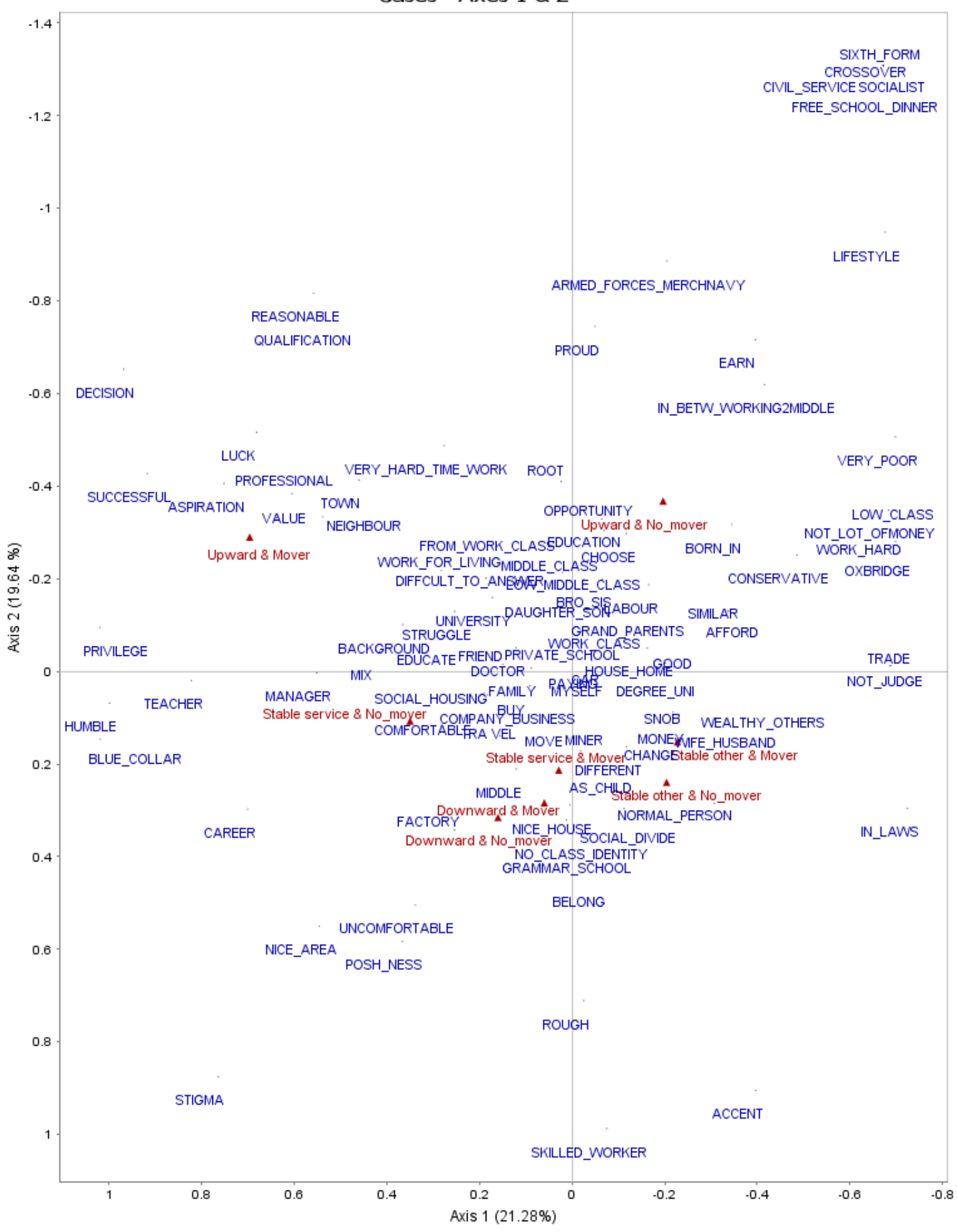


Figure 1b. Axes 1 and 2 supplementary categories

Frequencies - Axes 1 \& 2

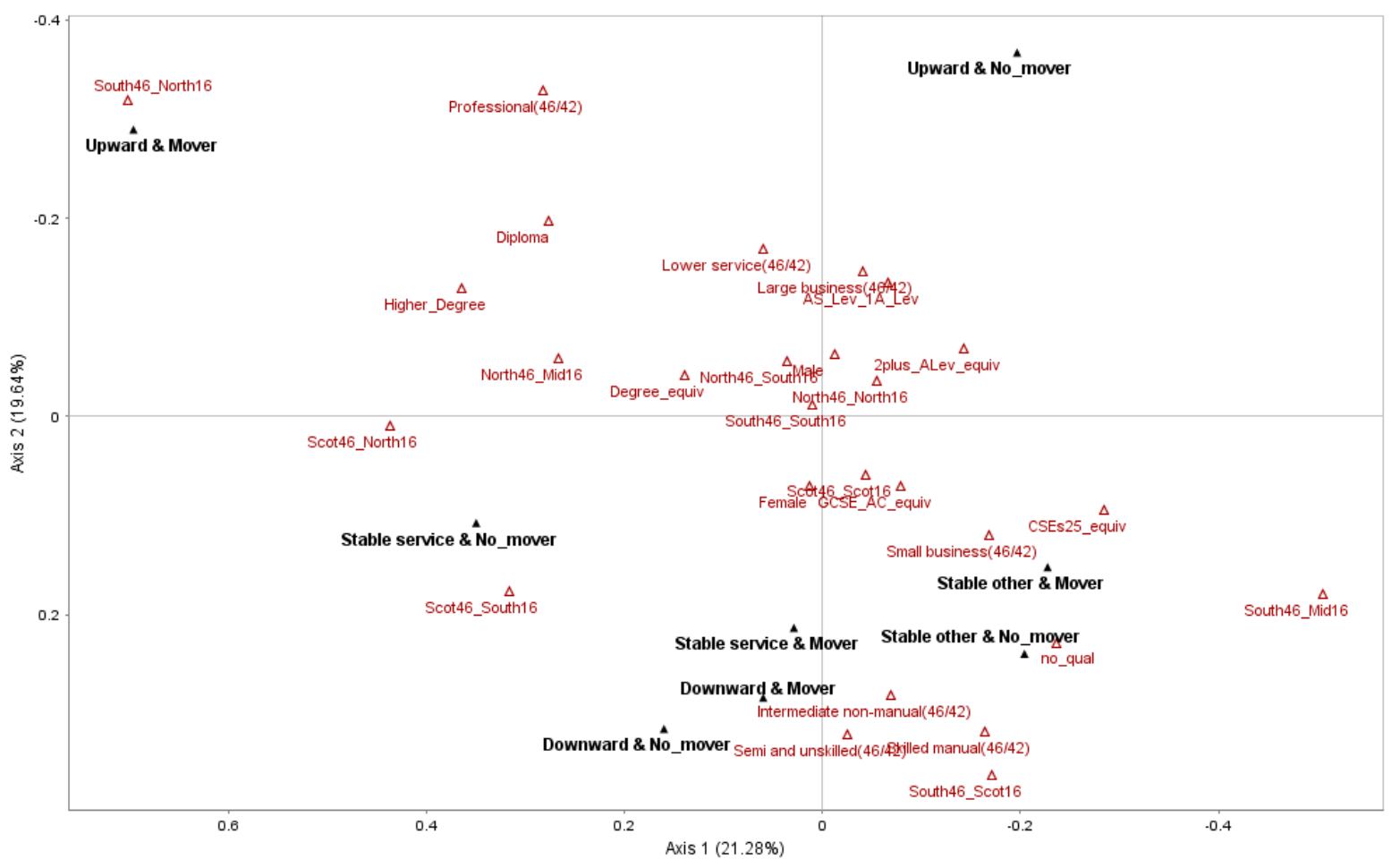


Figure 1c. Axes 1 and 2 interviewees by participant number

Frequencies - Axes 1 \& 2

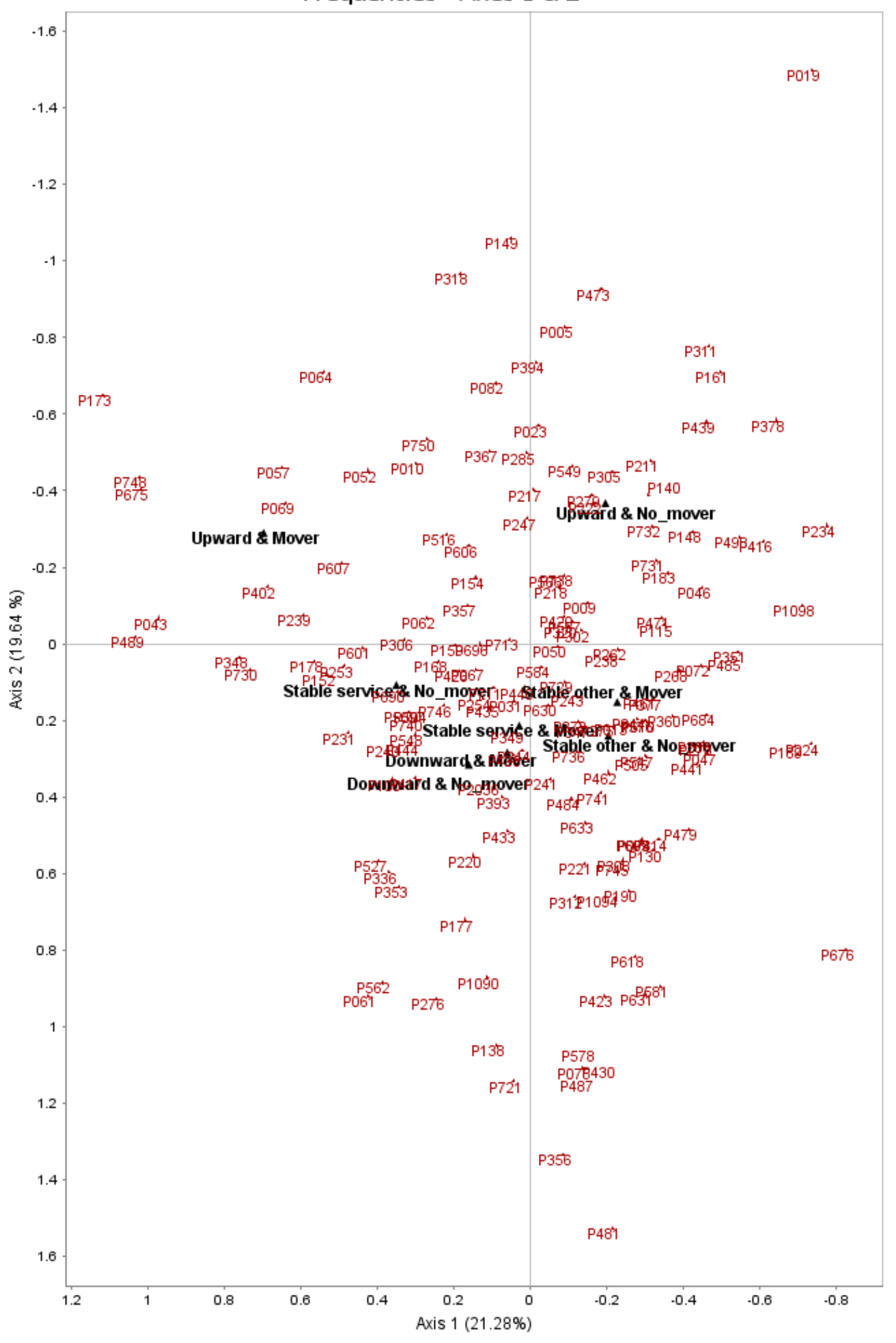


Figure 2a. Axes 1 and 3 active categories

Cases - Axes $1 \& 3$

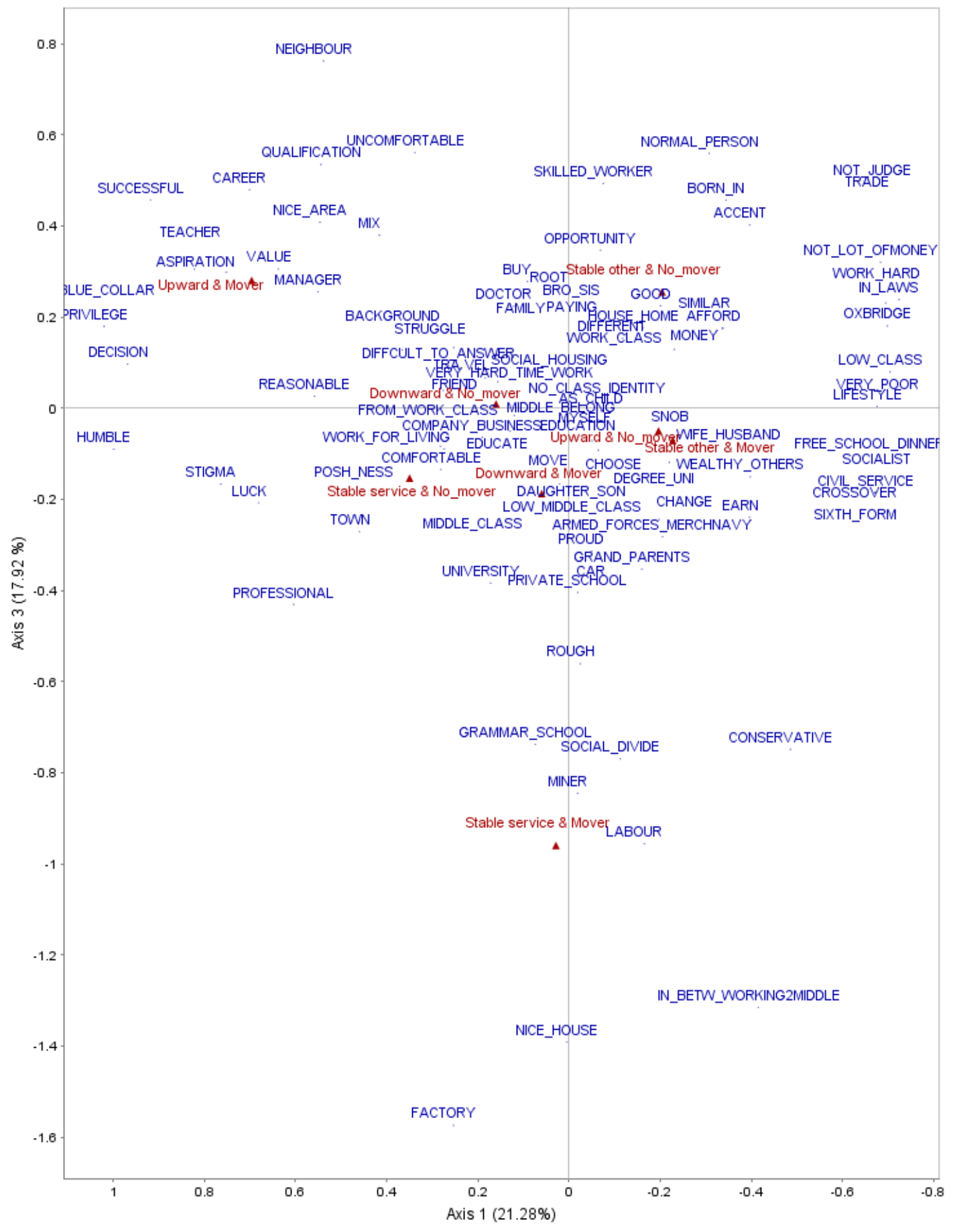


Figure 2b. Axes 1 and 3 supplementary categories

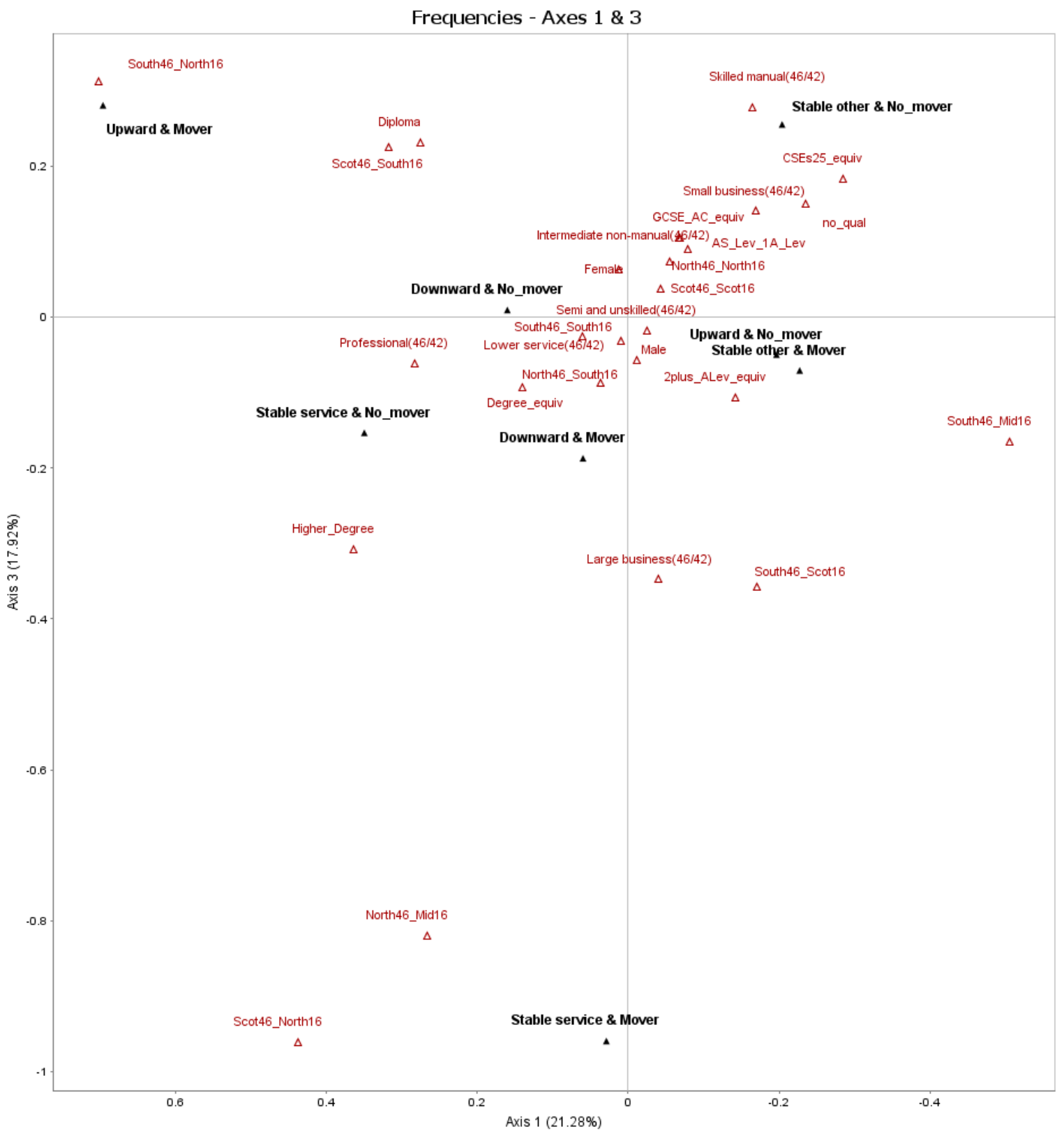




\section{Appendix}

Table A1. SCA variance

\begin{tabular}{cccc}
\hline Axis & Eigenvalue & Percentage & $\begin{array}{c}\text { Cumulated } \\
\text { Percentage }\end{array}$ \\
\hline 1 & 0.085 & 21.1 & 21.1 \\
2 & 0.08 & 19.8 & 40.9 \\
3 & 0.073 & 18.0 & 58.8 \\
4 & 0.053 & 13.1 & 71.9 \\
5 & 0.045 & 11.2 & 83.1 \\
6 & 0.037 & 9.3 & 92.4 \\
7 & 0.031 & 7.6 & 100 \\
\hline
\end{tabular}


Table A2. Top 20 axis contributions (words) and cumulated contributions (per cent)

\begin{tabular}{|c|c|c|}
\hline & \multicolumn{2}{|c|}{ Highest axis contributions } \\
\hline & Left/Down & Right/Up \\
\hline $\begin{array}{l}\text { Axis } 1 \\
(56.2)\end{array}$ & $\begin{array}{l}\text { Privilege, Teacher, Luck, Background, } \\
\text { Successful, Blue_Collar, Humble, } \\
\text { Middle_Class, Career, Professional, Value, } \\
\text { Decision, In_Laws }\end{array}$ & $\begin{array}{l}\text { Not_Lot_Ofmoney, Oxbridge, } \\
\text { Wealthy_Others, Low_Class, Lifestyle, } \\
\text { Work_Hard, Good }\end{array}$ \\
\hline $\begin{array}{l}\text { Axis } 2 \\
(66.4)\end{array}$ & $\begin{array}{l}\text { Belong, Posh_Ness, No_Class_Identity, } \\
\text { Accent, Stigma, Skilled_Worker, Rough }\end{array}$ & $\begin{array}{l}\text { Earn, Lifestyle, Very_Hard_Time_Work, } \\
\text { Crossover, Sixth_Form, Socialist, } \\
\text { Armed_Forces_Merchnavy, As_Child, } \\
\text { Middle_Class, Luck, Qualification, } \\
\text { Reasonable, Education }\end{array}$ \\
\hline $\begin{array}{l}\text { Axis } 3 \\
(69.6)\end{array}$ & $\begin{array}{l}\text { Factory, Nice_House, Social_Divide, } \\
\text { Grammar_School, In_Betw_Working2middle, } \\
\text { Middle_Class, Labour, Car, Miner, } \\
\text { University, Private_School, Conservative, } \\
\text { Change }\end{array}$ & $\begin{array}{l}\text { Normal_Person, Good, Neighbour, Mix, } \\
\text { Work_Class, House_Home, Uncomfortable }\end{array}$ \\
\hline $\begin{array}{l}\text { Axis } 4 \\
(70.6)\end{array}$ & $\begin{array}{l}\text { Buy, Grand_Parents, In_Laws, Money, } \\
\text { Friend, Car, Different, Social_Divide, } \\
\text { Degree_Uni, Company_Business, Neighbour, } \\
\text { Low_Class }\end{array}$ & $\begin{array}{l}\text { As_Child, Stigma, Work_Class, Belong, } \\
\text { No_Class_Identity, Afford, Similar, Bro_Sis }\end{array}$ \\
\hline
\end{tabular}


Table A3. Axis contributions (patterns of mobilities, per cent)

\begin{tabular}{lllll}
\hline Patterns of mobility-migration & $\begin{array}{l}\text { Contr } \\
\text { axis 1 }\end{array}$ & $\begin{array}{l}\text { Contr } \\
\text { axis 2 }\end{array}$ & $\begin{array}{l}\text { Contr } \\
\text { axis 3 }\end{array}$ & $\begin{array}{l}\text { Contr } \\
\text { axis 4 }\end{array}$ \\
\hline Downward \& Mover & 0.1 & 2.2 & 1.0 & 1.6 \\
Downward \& No_mover & 3.2 & 13.6 & 0.0 & $\mathbf{2 3 . 0}^{\mathbf{2}}$ \\
Stable other \& Mover & 4.2 & 2.0 & 0.5 & $\mathbf{3 6 . 5}^{\mathbf{3}}$ \\
Stable other \& No_mover & 12.0 & 18.0 & $\mathbf{2 2 . 4}^{\mathbf{2}}$ & 0.8 \\
Stable service \& Mover & 0.0 & 2.8 & $\mathbf{6 1 . 4}^{\mathbf{3}}$ & 6.1 \\
Stable service \& No_mover & 17.8 & 1.8 & 4.1 & 10.4 \\
Upward \& Mover & $\mathbf{4 9 . 3 ^ { 1 }}$ & 9.3 & 9.5 & 16.4 \\
Upward \& No_mover & 13.3 & $\mathbf{5 0 . 4}^{\mathbf{2}}$ & 1.0 & 5.1 \\
\hline
\end{tabular}

${ }^{1}$ : Category located at the left side of the axis

2: Category located at the upper side of the axis

3: Category located at the lower side of the axis 
Figure A1. Axes 1 and 3 interviewees by participant number

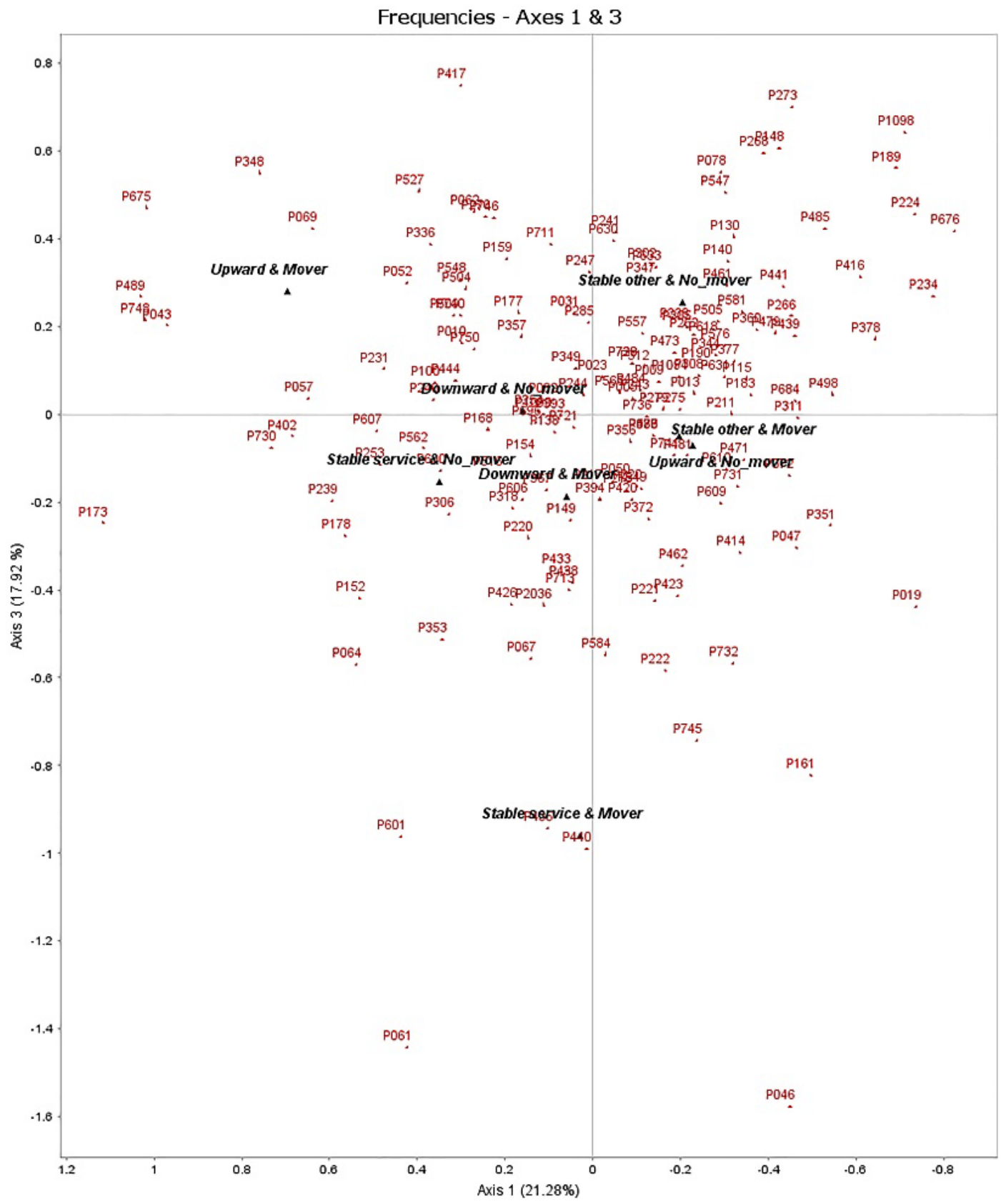




\section{Notes}

${ }^{i}$ https://www.channel4.com/news/factcheck/britains-social-mobility-crisis-in-ten-graphs ii Previously The Social Mobility and Child Poverty Commission (SMCP).

iii Inevitably the survey has suffered from attrition and non-response over the year. This is more noticeable in the case of those of more disadvantaged backgrounds. Nevertheless, the NCDS data has retained a high degree of national representativeness (Nathan 1999, Hawkes and Plewis 2006. See also Elliot et al 2010).

iv Social participation and identity. Combining quantitative longitudinal data with a qualitative investigation of a sub-sample of the 1958 Cohort Study. ESRC: (RES 50325 0001).

${ }^{v}$ A further 50 interviews were subsequently conducted with panel members living in Wales (Authors 2012).

vi In the RGSR classification we combine the 'Northern', 'North Western' and 'East and West Ridings' regions to form the North, which approximates to the 'North East, 'North West' and 'Yorkshire and Humber' regions in the GOR classification. For the Midlands, we combine 'Midland' and 'North Midland' from the RGSRs and 'West Midlands' and East Midlands' from the GORs. For the South we combine 'South Western', 'Southern'. 'London and South Eastern' and 'Eastern' from the RGSRs and 'South West', 'South East', 'London' and 'Eastern' from the GORs. Scotland, Wales and Northern Ireland are combined into one 'other' region because of the small sample sizes of NCDS participants in these locations.

vii Both from Provalis Prosuite https://provalisresearch.com/products/prosuite-text-analyticstools /

viii Textual content analysis combined with correspondence analysis is part of a rich tradition started by JP Benzecri and collaborators in the mid-60s (Murtagh 2005). Given the extensive use of (multiple) correspondence analysis by UK researchers inspired by the work of Pierre Bourdieu (e.g. Atkinson and Deeming 2015, Bennett et al, 2009, Miles and Sullivan 2011, Leguina and Miles 2017), it is perhaps surprising that this approach to quantitative textual analysis has rarely featured in Anglo-Saxon sociology. The use of SCA for textual analysis can be found in other fields of knowledge, such as communication, media and politics (Murtagh 2016.). 
ix The lexicological contingency table used for our analysis has 96 rows. Words with a frequency 2 or fewer were excluded from analysis. Word frequency in the analyzed table ranges from 3 to 127, with an average of 17.1 and standard deviation of 21.

x The variance decomposition in our SCA is shown in Table A1 in the Appendix to this paper.

xi The SCA biplots presented here are rows (dictionary entries) and columns (patterns of mobility-migration) in simultaneous representation. Unlike multiple correspondence analysis, separation between rows and columns does not represent genuine distance. Interpretation should be carried out carefully, in terms of attraction and focused on peripheral points (Le Roux and Rouanet 2004, Greenacre 2007).

xii The distribution of subsample participants on Axes 1 and 2 is shown in Figure 1c.

xiii The distribution of subsample participants on Axis 3 in the space is shown in Figure 1c. 


\section{Bibliography}

Atkinson, W. \& Deeming, C. 2015. 'Class and Cuisine in Contemporary Britain: The Social Space, the Space of Food and Their Homology', The Sociological Review 63(4): 876-96.

Bennett, T., Savage, M., Silva, E., Warde, A., Gayo-Cal, M., and Wright, D. 2009. Culture, Class, Distinction, London: Routledge.

Benson, M. 2014. 'Trajectories of Middle-class Belonging: The Dynamics of Place Attachment and Classed Identities', Urban Studies 51(14): 3097-3112.

Blanden, J., Goodman, A., Gregg, P. and Machin, S. 2004 'Changes in Intergenerational Mobility in Britain' in M. Corak (ed.) Generational Income Mobility in North America and Europe, Cambridge: Cambridge University Press.

Bottero, W. 2004. 'Class Identities and the Identity of Class', Sociology 38(5): 9851003.

Breen, R. and Goldthorpe, J.H. 2001. 'Class, Mobility and Merit. The Experience of Two British Birth Cohorts', European Sociological Review 17 (2) 81-101.

Bukodi, E, Goldthorpe, J.H., Waller, L, Kuha, J. 2015. 'The mobility problem in Britain: new findings from the analysis of birth cohort data', The British Journal of Sociology 66 (1): 93-117. 
Champion, T., Coombes, M. and Gordon, I. 2014. 'How Far do England's Second-order Cities Emulate London as Human-capital 'Escalators', Population, Space and Place 20(5): 421-33.

Chernillo, D. 2011. 'The Critique of Methodological Nationalism: Theory and History', Thesis Eleven 106(1): 98-117.

Chetty, R., Hendren, N. and Katz, L. 2016. 'The Effects of Exposure to Better Neighborhoods on Children: New Evidence from the Moving to Opportunity Experiment', American Economic Review, 106(4): 855-902.

Chetty, R., Hendren, N., Kline, P. and Saez, E. 2014, 'Where is the Land of Opportunity? The Geography of Intergenerational Mobility in the United States', Quarterly Journal of Economics 129(4): 1553-623.

Coheris. 2015. SPAD 8 User's Guide, Paris: Coheris.

Connelley, R., Gayle, V., Lambert, P.S. 2016. 'A Review of Occupation Based Social Classifications for Social Survey Research', Methodological Innovations, 9: $1-14$.

Crow, G. 2002. Social Solidarities: Theories, Identities and Social Change. Buckingham: Open University Press. 
Cunningham, N., Miles, A. and Leguina, A. 2018. 'The Ghosts of Class': Space, Waste and Hope in the Ex-Industrial North. In F. Dodsworth and A. Walford. (eds.) A World Laid Waste? Responding to the Social, Cultural and Political Consequences of Globalisation. London: Routledge.

DiMaggio, P., Nag, M. and Blei, D. 2013 'Exploiting affinities between topic modeling and the sociological perspective on culture: Application to newspaper coverage of U.S. government arts funding' Poetics 41(6): 570-606.

Elliott, J., Johnson, J., Shepherd, P. 2012. 'National Child Development Study. Revised Region Variables', London: Centre for Longitudinal Studies.

Elliott, J., Miles, A., Parsons, S. and Savage, M. 2010. 'The Design and Content of the "Social Participation" Study: A Qualitative Sub-Study Conducted as Part of the Age 50 (2008) Sweep of the National Child Development Study', CLS Working Paper 2010/3, London: Centre for Longitudinal Studies.

Erikson, R. and Goldthorpe J. H. 1992. The Constant Flux. A Study of Class Mobility in Industrial Societies, Oxford: Clarendon Press.

Favell, A. and Recchi, E. 2011. 'Social Mobility and Spatial Mobility', in A. Favell and V. Guiraudon (eds.) Sociology of the European Union, Basingstoke: Palgrave Macmillan, 50-75. 
Fielding, A. J. 1992. 'Migration and Social Mobility: South East England as an Escalator Region', Journal Regional Studies 26(1): 1-15.

Fielding, A. J. 1995. 'Migration and Social Change: A Longitudinal Study of the Social Mobility of 'Immigrants', European Journal of Population / Revue Européenne de Démographie 11(2): 107-121.

Friedman. S. 2016. 'Habitus clivé and the emotional imprint of social mobility', The Sociological Review 64(1): 129-147.

Friedman, S. and Laurison, D. 2017. 'Mind the Gap: Financial London and the Regional Class Pay Gap', The British Journal of Sociology 68(3): 474 - 511.

Friedman, S., Laurison, D. and Miles, A. 2015. 'Breaking the 'Class Ceiling'? Social Mobility into Britain's Elite Occupations', The Sociological Review 63(2): 259-89.

Friedman, S., and Macmillan, L. 2017. 'Is London Really the Engine-Room? Migration, Opportunity Hoarding and Regional Social Mobility in the UK', National Institute Economic Review 240(1): R58-R72.

Gardiner, B., Martin, R.L. and Tyler, P. 2013. 'Spatially unbalanced growth in the British economy', Journal of Economic Geography 13(6): 889-928.

Goldthorpe, J.H and Jackson, M. 2007. 'Intergenerational class mobility in 
contemporary Britain: political concerns and empirical findings', The British Journal of Sociology 58 (4): 525-546.

Goldthorpe J.H., Llewellyn, C. and Payne, C. 1987. Social Mobility and Class Structure in Modern Britain (2nd edn). Oxford: Clarendon Press.

Goodwin, M. and Heath, O. 2016. 'The 2016 Referendum, Brexit and the Left Behind: An Aggregate-level Analysis of the Result'. The Political Quarterly 8(3): 323-332.

Gouldner, A. W. 1957. 'Cosmopolitans and Locals: Toward an Analysis of Latent Social Roles', Administrative Science Quarterly 2(3): 281-306.

Greenacre, M. 2007. Correspondence analysis in practice (2nd edn). London: Chapman \& Hall.

Hawkes, D., and I. Plewis. 2006. 'Modelling Non-Response in the National Child Development Study', Journal of the Royal Statistical Society (Series a) 169(3): 479491.

Harris, J. 2016. 'Britain is in the midst of a working-class revolt', The Guardian (Online). Available at: https://www.theguardian.com/commentisfree/2016/jun/17/britain-working-classrevolt-eu-referendum (Accessed: 24 February 2017). 
Hill, B. and Lai, A.L. 2014. 'Class talk: habitus and class in parental narratives of school choice', Journal of Marketing Management 32(13): 1284-1307.

Ingram, N. 2011. 'Within school and beyond the gate: the complexities of being educationally successful and working class', Sociology 45 (2): 287-302.

Krzyżanowska M. and Mascie-Taylor C. G. N. 2012. 'Impact of Social Mobility and Geographical Migration on Variation in Male Height, Weight and Body Mass Index in a British Cohort', Journal of Biosocial Sciences 44: 221-228.

Laurison, D., and Friedman, S. 2016. 'The Class Pay Gap in Higher Professional and Managerial Occupations', American Sociological Review 81(4): 668-695.

Lawler, S. 2005. 'Disgusted Subjects: The Making of Middle-Class Identities', The Sociological Review 53(3): 429-446.

Le Roux, B. and Rouanet, H. 2004. Geometric Data Analysis: From Correspondence Analysis to Structured Data Analysis, Dordrecht: Kluwer Academic Publishers.

Lee, M. and Martin, J.L. 2015. 'Coding, Counting and Cultural Cartography', American Journal of Cultural Sociology 3(1): 1-33. 
Leguina, A. and Miles, A. 2017. 'Fields of Participation and Lifestyle in England: Revealing the Regional Dimension from a Reanalysis of the Taking Part Survey Using Multiple Factor Analysis', Cultural Trend 26(1): 4-17.

Massey, S.D. Gross, A.B. and Shibuya, K. 1994. 'Migration, Segregation, and the Geographic Concentration of Poverty', American Sociological Review 59(3): 425445 .

Miles, A. Savage, M. and BühImann, F. 2011. 'Telling a Modest Story: Accounts of Men's Upward Mobility from the National Child Development Study', The British Journal of Sociology 62(3): 418-41.

Miles, A. and Sullivan, A. 2012. 'Understanding Participation in Culture and Sport: Mixing Methods, Reordering Knowledges', Cultural Trends 21(4): 311-24.

Moody, K. 2016. 'Was Brexit a Working-Class Revolt?', Solidarity 13 September (Online). Available at: https://www.solidarity-us.org/node/4771 (Accessed: 24 February 2017).

Murtagh, F. 2005. Correspondence Analysis and Data Coding with $R$ and Java, London: Chapman \& Hall.

Murtagh F. 2016. 'The Geometry and Topology of Data and Information for Analytics of Processes and Behaviours: Building on Bourdieu and Addressing New Societal Challenges', In J. Blasius, B. Le Roux, F. Lebaron, and A. Schmitz (Eds.), 
Empirical Investigation of Social Space. Submitted, preprint:

https://arxiv.org/abs/1705.08503.

Murtagh, F., Pianosi, M. and Bull, R. 2015. 'Semantic Mapping of Discourse and Activity, Using Habermas's Theory of Communicative Action to Analyze Process', Quality \& Quantity 50(4): 1675.

Nathan, G. 1999. ‘A Review of Sample Attrition and Representativeness in Three Longitudinal Studies, Methodology Series 13'. London: Government Statistical Service.

Payne, G. 1973. 'Typologies of Middle Class Mobility', Sociology 7(3): 417-428.

Payne, G. 2017. The New Social Mobility: How the Politicians Got It Wrong. Bristol: Policy Press.

Provalis. 2015. Wordstat 11 User's Guide, Quebec: Provalis Research.

Rowthorn, R.E. 2010. 'Combined and Uneven Development: Reflections on the North-South Divide', Spatial Economic Analysis 5(4): 363-88.

Savage, M. 1988. 'The Missing Link? The Relationship between Spatial Mobility and Social Mobility', The British Journal of Sociology 39(4): 554-577. 
Savage, M. 2000. Class Analysis and Social Transformation. Milton Keynes: Open University Press.

Savage, M. 2010. Identities and Social Change in Britain since 1940: The Politics of Method. Oxford and New York: Oxford University Press.

Savage, M., Bagnall, G. and Longhurst, B.J. 2001. 'Ordinary, Ambivalent and Defensive: Class Identities in the Northwest of England', Sociology 35(4): 875-892.

Savage, M., Bagnall, G., and Longhurst, B. 2005. Globalisation and belonging. London: Sage.

Savage, M., Barlow, J., Dickens, P. and Fielding, T. 1992. Property, Bureaucracy, Culture. London: Routledge.

Savage, M., Devine, F., Cunningham, N., Taylor, M., Li, Y., Hjellbrekke, J, Le Roux, B., Friedman, S. and Miles, A. 2013. A new model of social class? Findings from the BBC's Great British Class Survey experiment, Sociology 47(2): 219-250.

Savage, M., Devine, F., Friedman, S., Cunningham, N., Laurison, D., Miles, A., Snee, H., Mackenzie, L. and Wakeling, P. 2015. Social Class in the 21st Century. London: Penguin. 
Sensier M. and Devine, F. 2017. 'Social Mobility and Brexit: A Closer Look At England's 'Left Behind' Communities', Economics Discussion Paper Series EDP1709, Manchester: University of Manchester.

Savage, M. and Egerton, M. 1997. 'Social Mobility, Individual Ability and the Inheritance of Class Inequality', Sociology, 31(4): 645-672.

Skeggs, B. 2004. Class, Self, Culture. London: Routledge.

Social Mobility and Child Poverty Commission. 2016. The Social Mobility Index, Available at: https://www.gov.uk/government/publications/social-mobility-index.

Sørensen, A.B. 1986. 'Theory and Methodology in Social Stratification'. In U. Himmelstrand (ed.) Sociology from Crisis to Science, London: Sage.

Sorokin, P.A. 1927. Social Mobility. California: Harper and Brothers.

Stoneman, P., Sturgis, Allum, N. 2012. 'Exploring public discourses about emerging technologies through statistical clustering of open-ended survey questions', Public Understanding of Science 22(7): 850-868.

Uhrig, S.C.N. 2008. 'The Nature and Causes of Attrition in the British Household Panel Survey', Essex: Institute for Economic and Social Research. 
University of London. Institute of Education. Centre for Longitudinal Studies.

2014. National Child Development Study: Childhood Data, Sweeps 0-3, 1958-1974.

[data collection]. 3rd Edition. National Birthday Trust Fund, National Children's

Bureau, [original data producer(s)]. UK Data Service. SN: 5565.

University of London. Institute of Education. Centre for Longitudinal Studies.

2008. National Child Development Study: Sweep 7, 2004-2005. [data collection]. 3rd Edition. UK Data Service. SN: 5579.

Watson, W. 1964. 'Social Mobility and Social Class in Industrial Communities', in M. Gluckman (ed.), Closed Systems and Open Minds, Chicago: Oliver \& Boyd. 